\title{
Financial Statement Analysis and Investment Decision Making in Commercial Banks: A Case of Bank of Kigali, Rwanda
}

\author{
Mukamwiza Berthilde*, Claude Rusibana \\ School of Business and Economics, Mount Kenya University, Kigali, Rwanda \\ Email: ${ }^{\star}$ muzimaberthilde@gmail.com
}

How to cite this paper: Berthilde, M., \& Rusibana, C. (2020). Financial Statement Analysis and Investment Decision Making in Commercial Banks: A Case of Bank of Kigali, Rwanda. Journal of Financial Risk Management, 9, 355-376.

https://doi.org/10.4236/jfrm.2020.94019

Received: August 26, 2020

Accepted: October 27, 2020

Published: October 30, 2020

Copyright $\odot 2020$ by author(s) and Scientific Research Publishing Inc. This work is licensed under the Creative Commons Attribution International License (CC BY 4.0).

http://creativecommons.org/licenses/by/4.0/

\begin{abstract}
This research analyzed the contribution of financial statements in investment decision making of banks in Rwanda taking the case of bank of Kigali. The study ascertained benefits of financial statements analysis; it analyzed obstacles of investment decisions faced by Bank of Kigali; and it established the correlation of investment decisions and financial statements analysis of Bank of Kigali. This study is significant to different beneficiaries, such as researcher, other researchers and National Bank of Rwanda. Both a descriptive and a correlational research design were adopted and quantitative and qualitative methods were used 0.126 managers were targeted and 96 managers were sampled and a stratified random sampling technique was utilized in bank of Kigali. Data from the field was collected using questionnaire and a documentary analysis where financial reports of the bank from 2014 to 2018 were analyzed. This research used correlation analysis and SPSS version 22.0 for analysis. The finding revealed that holding independent variables constant to a constant zero, short term investment decision would be at 0.266 for common size analysis while the most significant $p$-value was 0.008 . The finding revealed that holding independent variables constant to a constant zero, Vertical analysis would be at 0.215 for horizontal analysis and element enhanced ratio analysis in the term investment decision limited by a factor of 0.001 correlated with the long term investment decision. It is concluded that understanding financial statement analysis provides that is very important to those who have the businesses as tools for reducing the considerable risks involved in starting and growing the business. Financial status of Bank of Kigali need to be maintained through the enhancement of good flow of deposits, savings and repayment arrangements to enable it serve its members while enhancing quality decisions for better service provision and also there is a need to invest in business, technology, product development, training and effective risk
\end{abstract}


management systems that may be facilitated by bold decisions for the life of the company. It is also recommended to always mitigate risks while enhancing innovations and development.

\section{Keywords}

Financial Statement, Analysis, Investment Decision Making

\section{Introduction}

The present chapter provides the background to the study problem statement, objectives, and research questions, significance of the study, limitations, scope and organization of the research reports.

\subsection{Background of the Study}

Financial information appears as a very crucial tool. It guides to know how the past has been, how the present is, and forecast the future. Information will be like an order to plan one's activities accordingly (Capital Market Authority, 2013). In business, financial information helps its users predict the amount, time and inevitability of cash flows for making decisions. Like any language, financial statements are primarily a communication tool; it is important that one use appropriate, accurate and precise language. Financial statements in developing countries like United States of America (USA) provide evidences and facts related to banks' development. Therefore, financial analysis objective is to offer evidences related to financial position, the attainment of expected outcomes and ability of a bank that is prominent for customers in stimulating the resolution of economic problems (Barry \& Jamie, 2011).

In European commercial banks, financial statements explained banking activities into objective in provision of evidences and facts related to the bank success, pertinent issues and strategies to overcome those issues. Therefore, knowledge and skills of financial analysis are very necessary for different people such as investors, creditors and regulators. Like ballplayers who could not manage score, an operating manager who did not fully acquire awareness related to accounting and finance working conditions under an unnecessary handicap (Higgins, 2012).

The ultimate goal of financial statement in Africa is of offer financial information to stakeholders. In this regards, the financial Accounting Standards Board (FASB) is responsible for setting up the international accounting standards (David, 2006). The aforementioned standards address accounting treatment of business transaction and disclosing the same in financial statements issues. Accounting afford information and evidences to internal and external users.

Financial statements in Rwandan commercial banks perspective are very useful in the investment decisions of commercial banks (Alfred, 2013). However, 
the lack of financial information to the stakeholder can cause non-effective investment decisions of many commercial banks in Rwanda. With the purpose to avail reliable financial evidences and implement the culture of qualitative reporting, effective financial statements are getting more and more required in commercial banks (Rwemalika, 2013). The researcher carried out a study by analyzing how economic factors contribute to the profitability of commercial in Rwanda.

\subsection{Statement of the Problem}

Although financial statements is the activity related to the provision of adequate information for adopting necessary options and importance of financial statement in banking sector (Kamardin, 2014), commercial banks in less developed countries is constrained by several challenges including macroeconomic instability, instability of stock markets and inadequacy of the advancement and specialization of banks and thus justifies the reason why customers are dedicated to Financial statements to use in examining the performance of bank and involved for making decisions (Mckeith, 2010). The study of Fisseha (2015) indicated that mosts of banks are failing and this is frequently happened in most of developing countries, he found that globally between 2007 and 2013 there was the wave of low performance for banking industry and unpredictable events appeared due to the lack of effective banks decision on investment. Therefore, most commercial banks in Rwanda to determine its financial position and their earning capacity they use financial statement, but they do not apply them while they are making decision. Therefore, from the above problem the researcher needs to carry out the study on financial statements and the investment decision of commercial banks.

\subsection{Objectives of the Study}

This research will analyse how financial statement analysis in investment decisions contribute to the quality service provision of Bank of Kigali Ltd.

\subsubsection{General Objectives}

This research analyzed the contribution of financial statement on investment making of commercial banks.

\subsubsection{Specific Objectives}

1) To ascertain benefits of financial statements analysis in banks.

2) To analyze the obstacles of investment decisions in banks.

3) What is the financial statement relationship and investment decisions in banks.

\subsection{Research Questions}

1) Is there any benefit of financial statements analysis in banks?

2) Is there any obstacle of investment decisions faced by Bank of Kigali?

3) Is there any relationship between financial statements analysis and investment decisions of Bank of Kigali? 


\subsection{Study Significance}

Results from the present research are significant on different beneficiaries, such as researcher, other researchers and National Bank of Rwanda. The project should help the researcher to increase knowledge on investment in banks. It should also help him to know much more the various accounting bodies that should be established to provide principles governing financial reporting. This study would be helpful for different stakeholders of an enterprise that are concerned for their respective decisions.

This project should serve the National Bank of Rwanda to know the level of application of financial statements analysis in the banking sector as well as its contribution in development of this sector. Also in these study recommendations regarding the banking sector in Rwanda should be made for the improvement.

\section{Review of Related Literature}

\subsection{Financial Statements}

Financial statement is a process of communication financial facts. To be successful, this communication must be appropriate and adequate enough for accounting principles, the level of awareness by managers of financial statements, (AICPA, 2013).

Accordingly, the bank annual report has to assess their achievement of expected target through issuance of prominent financial statements including balance sheet, profit and loss statements, statement of adjustments in stakeholder equity and cash flow statements (Solberg \& Durrieu, 2006). Financial statements afforded evidences related to the banking conditions at a point in period of time (Deming, 2005). Therefore, financial statements are capable of predicting the possible future success of the organization. These are helpful in anticipating the future working conditions of any institution, as starting point for design and plan of actions include the future situations (Penman, 2007). Evidences embedded within financial statements could be used to calculate and assess the degree and riskiness of expected future cash flow as for the company.

Financial statements standards and practices have in the current come under great critics, requesting that accountants took further steps to be sure that the equity and fair view of the actual value of business are included in the financial statements published by them (Higgins, 2012).

Financial statements practices in Kenya are evidenced to be correlated with the execution of international standards in accounting and auditing. Several banks failure to manipulate resources adjustment in the financial statements of some large enterprises in the 1990 for the provision of examples of unsatisfied quality of financial statements (Vincent \& Schipper, 2003).

In Rwanda, banks had adopted international financial statement standards by international accounting standard boards. Their financial statements are prepared according to IFRS guidance and review the financial position and success. 
Annual accounts are audited with quarterly financial banks to elucidate topic related to external auditing (International Monetary Fund, IMF, 2011).

\subsection{Tapes of Financial Statement}

Balance sheet is thought to a snapshot, since its reports the company at specific period of time. It reflects the current period of time and past period so that financial statements reading can determine positive changes (Ojo, 2012).

Income statement is related to the motion picture, since it provides information on how companies are performing during a predetermined time. Income statement indicated record of a bank working findings for the entire year and it is used as a guideline for anticipation on how the firm can work in other times (Donald \& Delno, 2006).

Financial statement changes in stakeholders equity combined the activtiies in the equity section of the balance sheet from time to time. However, changes in stakeholder equity result from benefits or loss, dividends and stock issuance (Ebimobowei, 2012). Therefore, dividends are payment to shareholders for compensation them on their decision.

Statement of cash flow argues the canes in cash emanating from business operations. In this regards, cash flow analysis is very important to render proper investment decision and maintain operations.

\subsection{The Role of Financial Statements in Commercial Banks}

The company is undertaken using trend analysis; it is possible to do more detailed analysis adopting accounting ratios. The above ratio took into consideration the best and the worst achievement and determined clear adjustment.

According to Mckeith (2010), a ratio defines the correlation between accounting numbers in the financial statements. It is budget ration for the same period of time Annual financial statement of any institution provides a lot of financial evidences that its not easy for interpretation.

The ratio analyzed is very useful for stakeholders in a company while the liquidity of business that would be helpful in these perspectives. Lenders are interested in risk taking of the organization to be sure with the overexposing of the debt bad repayment mechanisms.

\subsection{Instrument of Decision Making}

In order to make and elucidate adequate and appropriate decisions many company management teams went through a systematic decision making process (Afolabi, 2013). However, the primordial practices can be the same while there are a dozens of decision making instruments. These include decision matrix model which adopts the utilization of graphs, models or pie charts. A decision matrix is used to assess all the alternative strategies of decision. Even if there is a use of the matrix, establishing a table is necessary with all alternatives in the first column and all of the factors associated with decision making in the first row 
(Ali, 2011).

\subsection{Empirical Literature}

Ojo (2012) carried out a scientific research aimed at obtaining ideas and perceptions of stakeholders on the obedience of regulations and rules related to financial statement in selected primary mortgage institutions in Nigeria. The study adopted both primary source by administering and questionnaire and collecting responses from the field while secondary data was obtaining using the existing available documents related to the research topic Different respondents were used. These include 30 regulators from two banks meaning 15 respondents for each institution. In addition, the researcher distributed questionnaire among 40 respondents for each of the organization cited above. Furthermore, some questionnaire for managers of banks and public institutions were distributed to people owing to their approximate to the streets that had awareness of the research topic. The above research evidenced that PMI is collecting rules and regulations related to financial statement. In this research stakeholders remarked that organization of companies related to the adequate practices in PMI affect their submission to regulation, rules and laws related to financial reporting while they did not appreciate the previous related practices.

The purpose was to treat the effect of financial statement on the effectiveness of management decision making process in Nigeria using 10 chosen key informants. In addition, 50 accountants, investment and financial analysts were required to provide responses in order to obtain relevant information. The analysis of variance was used for testing the research hypothesis and the study findings contended that financial statements disclosure, corporate fraud and scandals and financial statements transparency had a positive Impact on effective management of decision making in banking sector concerning investment in manufacturing sector in Nigeria.

Hassan (2013) carried out a research work named "Financial statements. For this research, correlation research design was used. A correlation research design was used to explain the statistical association between two variables. The Researcher found the research design to be adequate to the research process when it is has the ability to test expected correlation between variables. A longitudinal panel from secondary data was used where a quantitative approach with positivism paradigm and the core of relevant information for data analysis were appropriately obtained from financial report after auditing activities were performed. Multivariate analysis was used to assess the model while longitudinal panel helped to obtain heterogeneity from individual respondents. Results demonstrated implication of crucial policies since they proposed the necessity to stimulate the application of corporate governance principles by banks and individual stakeholders to afford monitoring of profit management in Nigeria.

Kamardin (2014) conducted a scientific work which objective was to address concepts and issues of IFRS and its relationship with corporate business. To 
bring clarility in this problem, the adoption of IFRS in the context of transforming financial reports, the research used a review model. It reflected on the analysis of discourses with evidences from documentary analysis through a systematic examination of publication and the existing literature on professional accounting organizations and academic studies conducted in the past. The study argued that there is a high degree of compliance and adoption of financial institutions and banking companies.

Kusa (2013) conducted a scientific research, results indicated that bank specific factors are more likely to impact the success of them. However, the general impact of macroeconomic factors was inconstancy with 5\% significant level. Therefore, concluding remarks argued that banks performance in Kenya is related to board and management decisions, while macroeconomic variables have negative significance role.

Hawariah and Dalnial (2014) conducted a research called Detecting Fraudulent Financial statements through Financial Statement Analysis. Past studies indicated that indication of financial ratio for detecting fraudulent statements and the sample size was firms in Malaysia and information used ranged between 2000 and 2011 years. Results evidenced that different financial ratios including debt to total financial resource, receivable to income are discovered to be correlated with detecting fraudulent financial reporting.

Kariuki and Jagongo (2013) carried out a research called instutionsl investors perception on qulaity of financial statements in Kenya. These researchers assessed both primary and secondary data source adopting a descriptive statistic. They revealed that information in the financial reports that very important for investors in total assets, income and earnings, cash flows from investing activities. The financial report is seen in the context of completeness, comparability and consistencies as the best, relevancy and forecasting and timeliness (Ingram, 1994). Furthermore, the study argues that the greatest impediment to the users of financial reports in Kenya is related to technical nature of language of presentation. Even if their research was very useful for Kenya companies, their research does not explore the correlation of financial statements and performance of companies in Kenya using Pearson correlation coefficient and profitability indicators.

\subsection{Critical Review and Research Gap Identification}

Kariuki \& Jagongo (2013) conducted a study called instutional investors perception on qulaity of financial statements in Kenya. This research determined type if information includes in the financial reports considered as crucial and prominent for banking institutions in Kenya. It identified institution investor's and their point of view on the usefulness of information on the process of decision making with regards to investment in banking sector and the study assessed challenges faced by investors. Even if their research was very useful for Kenya companies they fail to show the correlation of financial statement and perfor- 
mance of these companies in Kenya using Pearson correlation coefficient and profitability indicators. Hawariah and Dalnial (2014) conducted a research called Detecting Fraudulent Financial statements through Financial Statement analysis. Hence, from the above critics, the researcher found a gap, whereby, the above researchers did not use profitability ratios and correlation coefficients to analyze the variables of the study and level of investment decision making of the company.

\subsection{Conceptual Framework}

The conceptual framework (Figure 1) is a study instrument aimed at assisting the researcher to improve awareness and knowledge of the working conditions and communication process.

The independent variable in this study was financial statement analysis expressed in ratio analysis, common size analysis, vertical analysis and horizontal analysis. In this study, the dependent variable is the investment decision making which is expressed in terms of dividends payment. Apart from dependent and independent variables, there is intervening variable with other influences on decision making, like accounting standards and BNR policies. If these variables are not controlled well, they may interfere with the results of the study.

\subsection{Summary}

Financial statements, commercial banks and the linked concepts have been discussed in this chapter. The present chapter looks at what the researcher has gained from the review of what other authors say on the topic under the research. The literature available shows how financial statements can contribute on performance banks.

\section{Research Methodolgy}

This study adopted a descriptive and correlation research design through the use of both qualitative and quantitative approaches. These approaches involve gathering information in the context of testing and questionnaire survey to provide responses related to predetermined questions.

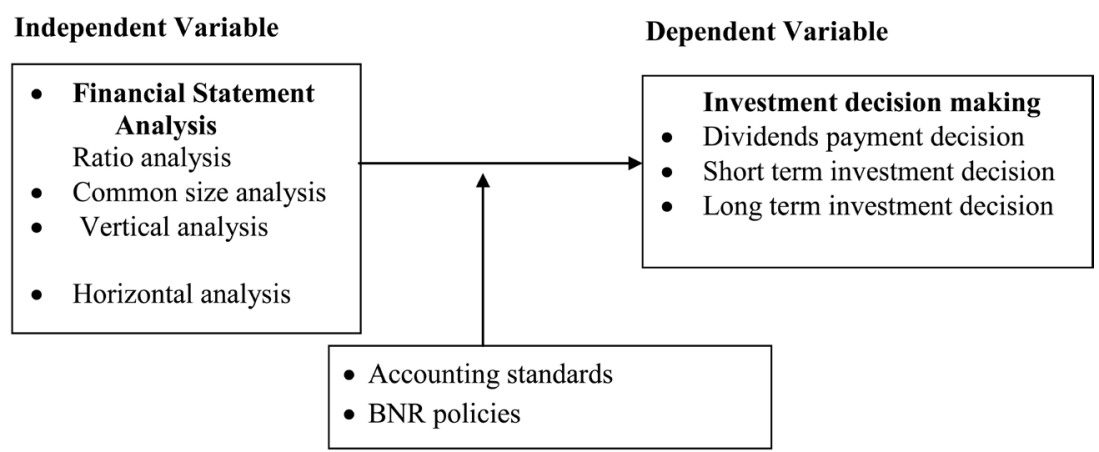

Source: (Researcher,2020)

Figure 1. Conceptual framework. 


\subsection{Target Population}

The target population is the subjects, individuals or group of other items that are deemed to have relevant opinions on the study. However, the present study targeted 126 respondents from the Bank of Kigali. The researcher selected managers due to the fact that they ate them who are responsible to make decisions in the banking settings.

\subsection{Sample Design}

A research design provides information related to sampling procedures, sampling techniques and sample size determination and calculation as explained more in the following subheadings.

\subsubsection{Sample Size}

Reconsidering that the size of target population was 126 , in order to determine or calculate sample size, the researcher uses the formula of Yamane. In this vein, the precision error is $5 \%$ and the confidential interval is $95 \%$ while the total population size is shown by $\mathrm{N}$ and the sample size by $\mathrm{n}$. The formula was expressed as follows:

$$
n=\frac{N}{1+N(e)^{2}}=\frac{126}{1+126(0.05)^{2}}=96 .
$$

It is on this ground that the researcher selected $59 \mathrm{BK}$ lower managers, $18 \mathrm{BK}$ middle managers, $10 \mathrm{BK}$ senior managers and 9 boards of directors and executives. The ultimate goal was to involve all the target population in an attempt to find solutions to the research problem.

Table 1 indicates Population and sample size was used in the study.

\subsubsection{Sampling Methods}

According to Kothari (2004), this researcher used a stratified sampling technique was representative groups of elements under investigation were found through their corresponding strata. According to Westfall (2009), in fact, to facilitate the selection of sampled population that may be relevant for the provision of relevant information to the subject under investigation the systematic random sampling was used.

Therefore, stratum was used due to the lack of homogeneity in target population. After categorizing respondents in their corresponding stratum, it was

Table 1. Population and sample size.

\begin{tabular}{cccc}
\hline Level of management & Target Population & Proportion & Sample Size \\
\hline Boards of directors and executives' managers & 12 & 9.52 & 9 \\
Senior managers & 13 & 10.32 & 10 \\
Middle management & 24 & 19.05 & 18 \\
Lower managers & 77 & 61.11 & 59 \\
Total & 126 & 100 & 96 \\
\hline
\end{tabular}


necessary to choose them based on the probability of selection for each member of the strata.

\subsection{Methods of Data Collection}

Primary information was collected using a questionnaire while secondary data was acquired using documentary analysis through the review of the existing documents available to the bank. These include financial statements, annual reports and other relevant documents related to the research topic. In order to obtain qualitative data, the researcher used interview guides.

\subsubsection{Instruments}

A questionnaire was distributed among sampled population. In this regards, it was formulated using questionnaire. The use of open ended questionnaire was helpful to the researcher to obtain in deep respondents and information while closed ended questions helped to obtaining information regarding predetermined responses subject to the sampled population. Therefore, secondary information was obtaining through an intensive analysis of annual reports of 2014 to 2018 .

\subsubsection{Administration of Research Instruments}

It was very important to administer questionnaire to the sampled population which in turn was responded and the research acquire information. Therefore, after collecting data, the research preceded data entry, coding, editing, classifying, categorizing and tabulation in order to eliminate errors, correct mistakes and adjust the meaning of responses. This step facilitated the interpretation and analysis of information collected.

\subsubsection{Validity and Reliability}

The ultimate goal of reliability of research instruments is to obtain the consistency and uniformity of responses and information collected. This is regarded as assessing many times through an assessment of the relevancy of the research instruments, clarity and hesitation on data collection tools. In order to obtain reliability, a pilot study was carried out on 10 persons working in banking sector. Research validity of data collection instruments was assessed through an outside people of languages and contents.

\subsection{Data Analysis Procedure}

The process of information collected through edit, code and tabulate. The phase of data processing helped the researcher to eliminate errors, correct mistakes and fill the missing. After data processing, data analysis, presentation and analysis were performed using SPSS. This study performed a regression analysis to demonstrate the correlation between financial statement and banking growth.

\subsection{Ethical Consideration}

After getting an authorization letter for conducting research, the researcher got 
permission from the authorities of BK. The researcher got consent from respondents where the participation was voluntarily and the confidentiality was ensured. There will be a deep explanation of the academic purpose of the present research.

\section{Results Analysis and Discussions}

\subsection{Identification of Respondents}

Personal attributes including sex, education, parents' living status, age has a positive impact to the study results. The socio-economic characteristics of respondent's, presented involving the gender, age group, marital status and education as wells as occupation.

\subsubsection{Gender of Respondents}

It is important to present gender characteristic of respondents to see whether they give any significant different views regarding the study.

According to this Table 2, male is higher than female which represents $55 \%$ of respondents while the female represents $45 \%$ respondents. This implies that this research benefited views from male and female at a considerable level. The researcher clearly observed from the findings that the number of male customers in the Bank of Kigali is more than the number of female. However the gap between men and male cannot be attributed to gender balance discrimination, as being becoming a client in BK base personal willingness and motivation instead of any other discriminatory based on gender.

\subsubsection{Age of Respondents}

Age group of respondents is an important variable as it allowed the researcher in determining the maturity of the answer in order to get credible information that is vital in this research.

Research findings showed that the age group of the respondents where $5 \%$ of respondents are under 20 years, $20 \%$ are in the range of $21-30$ years, $62.5 \%$ were aged in the range of 31 - 40 years, while $12.5 \%$ of respondents were in the range of above 41 years. As shown in Table 3.

\subsubsection{Education Level}

Data findings on educational level of respondents show that most employees can be effective in financial statements strategies in accordance with skills they have. However, looking at the table indicates that most employees are more educated.

Table 2. Distribution of the respondents by the gender.

\begin{tabular}{ccc}
\hline Gender of respondents & Frequency & Percent \\
\hline Male & 53 & 55.0 \\
Female & 43 & 45.0 \\
Total & 96 & 100.0 \\
\hline
\end{tabular}


Table 3. Age of respondents.

\begin{tabular}{ccc}
\hline Age of respondents & Frequency & Percent \\
\hline Under 20 years & 5 & 5.0 \\
$21-30$ years & 19 & 20.0 \\
31 - 40 years & 60 & 62.5 \\
41 years and above & 12 & 12.5 \\
Total & 96 & 100.0 \\
\hline
\end{tabular}

Table 4. Education level of respondents.

\begin{tabular}{ccc}
\hline Education level & Frequency & Percent \\
\hline Masters and above & 22 & 22.5 \\
Bachelor's degree & 62 & 65.0 \\
Secondary level & 12 & 12.5 \\
Total & 96 & 100.0 \\
\hline
\end{tabular}

The results from present research in Table 4 demonstrated that all the respondents were educated at different levels as it corresponds to their qualifications. The highest number of respondents was bachelor's degree level with $65 \%$ of all respondents. This is followed by master's degree holders with $22.5 \%$ of the respondents while only $12.5 \%$ of all respondents were of the secondary level. The research evidenced that since most of respondents are skilled, this enables them to the provision of evidences for the ultimate goal of the present research. The study findings are reliable and valid taking into consideration the quality of the source of data collected.

\subsection{Presentation of Findings}

Section two provides frequency of responses for employees in the Bank of Kigali relying on the research objectives. This research had financial statements analysis as independent variable and investment decision making as dependent. Employees were requested to indicate their opinion of the frequency of occurrence on each element.

\subsubsection{Analysis of Financial Statements Strategies in the Bank of Kigali}

Objective one determined the benefits of financial statements analysis in Bank of Kigali-Rwanda. The financial statement analysis is defined as an important to management, to investors to creditors, to tax authorities and to researchers.

Results in Table 5 indicate that $60 \%$ show a great extent to which ratio analysis is used within the Bank of Kigali, $20 \%$ for a very extent and $17.5 \%$ demonstrated a moderate extent ratio analysis is adopted in the Bank of Kigali. Finally only $2.5 \%$ of respondents evidenced a little extent to which the ratio analysis is applied in the bank. 
Table 6 indicates Common size analysi. It is clear that 55\% show a great extent to which common size analysis is used within the Bank of Kigali, 7.5\% for a very extent and $12.5 \%$ demonstrated a moderate extent common size analysis is adopted by the Bank of Kigali. Finally only $22.5 \%$ of respondents evidenced a little extent to which the common size analysis $t$ is applied in the bank and only 2.5 did not want to reveal the extent to which their agree with the statement.

As reflected in Table 7, it indicates $70.0 \%$ show a great extent to which vertical analysis is used in Bank of Kigali, 7.5\% for a very extent and 17.5\% demonstrated a moderate extent vertical analysis is adopted in Bank of Kigali. Finally only $10.0 \%$ of respondents evidenced a little extent to which the vertical analysis is applied in the bank and only 2.5 did not want to reveal the extent to which they agree with the statement.

Results in Table 8 indicate that $52.5 \%$ show a great extent to which horizontal analysis is used by Bank of Kigali, 5.0\% for a very extent and 12.5\% demonstrated a moderate extent horizontal analysis is adopted by Bank of Kigali. Finally only

Table 5. Ratio analysis.

\begin{tabular}{ccc}
\hline Ratio analysis & Frequency & Percent \\
\hline To little extent & 2 & 2.5 \\
To a moderate extent & 17 & 17.5 \\
To a great extent & 58 & 60.0 \\
To very great extent & 19 & 20.0 \\
Total & 96 & 100.0 \\
\hline
\end{tabular}

Table 6. Common size analysis.

\begin{tabular}{ccc}
\hline Common size analysis & Frequency & Percent \\
\hline To no extent & 2 & 2.5 \\
To a little extent & 22 & 22.5 \\
To a moderate extent & 12 & 12.5 \\
To a great extent & 53 & 55.0 \\
To a very great extent & 7 & 7.5 \\
Total & 96 & 100.0 \\
\hline
\end{tabular}

Table 7. Vertical analysis.

\begin{tabular}{ccc}
\hline Vertical analysis & Frequency & Percent \\
\hline To a little extent & 2 & 2.5 \\
To moderate extent & 9 & 10.0 \\
To a great extent & 68 & 70.0 \\
To a very great extent & 17 & 17.5 \\
Total & 96 & 100.0 \\
\hline
\end{tabular}


Table 8. Horizontal analysis.

\begin{tabular}{ccc}
\hline Horizontal analysis & Frequency & Percent \\
\hline To no extent & 9 & 10.0 \\
To a little extent & 19 & 20.0 \\
To a moderate extent & 12 & 12.5 \\
To a great extent & 51 & 52.5 \\
To a very great extent & 5 & 5.0 \\
Total & 96 & 100.0 \\
\hline
\end{tabular}

$20.0 \%$ of respondents evidenced a little extent to which the horizontal analysis is applied in the bank and only $10.0 \%$ did not want to reveal the extent to which they agree with the statement. As indicates in Table 8 of Horizontal analysis

\subsubsection{Identification of the Investment Decision Making Made by the Bank of Kigali-Rwanda}

The second objective identified the investment decision making made by the Bank of Kigali-Rwanda. These include the following but not exhaustive: dividends payment decision, short term and long term investment decision.

As presented in Table 9, 52.5\% show a great extent to which the dividends payment decision is used by the Bank of Kigali, 7.5\% for a very extent and 30.0\% demonstrated a moderate extent dividends payment decision is adopted by the Bank of Kigali. Finally only $5.0 \%$ of respondents evidenced a little extent to which the dividends payment decision is applied within the bank of Kigali and only $5.0 \%$ did not want to reveal the extent to which their agree with the statement.

Findings indicate that $60.0 \%$ show a great extent to which short term investment decision in the Bank of Kigali, 5.0\% for a very extent and $12.5 \%$ demonstrated a moderate extent short term investment decision is adopted in the Bank of Kigali. Finally only $12.5 \%$ of respondents evidenced a little extent to which the short term investment decision is applied in the bank of Kigali and only 10.0\% did not want to reveal the extent to which they agree with the statement. As shown in Table 10 .

Results presented in Table 11 indicated $50.0 \%$ show a great extent to which long term investment decision is used by the Bank of Kigali, $20.0 \%$ for a very extent and $22.5 \%$ demonstrated a moderate extent long term investment decision is adopted by Bank of Kigali. Finally, only $5.0 \%$ of respondents evidenced a little extent to which the long term investment decision is applied by the bank of Kigali and only $10.0 \%$ did not want to reveal the extent to which their agree with the statement.

\subsubsection{Relationship between Financial Statement Analysis and Investment Decision Making in the Bank of Kigali}

Objective three illustrates correlation between financial statements analysis 
Table 9. Dividends payment decision.

\begin{tabular}{ccc}
\hline Dividends payment decision & Frequency & Percent \\
\hline To no extent & 5 & 5.0 \\
To a little extent & 5 & 5.0 \\
To a moderate extent & 29 & 30.0 \\
To a great extent & 50 & 52.5 \\
To a very great extent & 7 & 7.5 \\
Total & 96 & 100.0 \\
\hline
\end{tabular}

Table 10. Short term investment decision.

\begin{tabular}{ccc}
\hline Short term investment decision & Frequency & Percent \\
\hline To no extent & 9 & 10.0 \\
To little extent & 12 & 12.5 \\
To moderate extent & 12 & 12.5 \\
To great extent & 59 & 60.0 \\
To very great extent & 4 & 5.0 \\
Total & 96 & 100.0
\end{tabular}

Table 11. Long term investment decision.

\begin{tabular}{ccc}
\hline Long term investment decision & Frequency & Percent \\
\hline To no extent & 2 & 2.5 \\
To a little extent & 4 & 5.0 \\
To a moderate extent & 22 & 22.5 \\
To a great extent & 48 & 50.0 \\
To a very great extent & 19 & 20.0 \\
Total & 96 & 100.0 \\
\hline
\end{tabular}

expressed in its mains components, investment decision making indicators as well as intervening variable as expressed in concept framework of this study.

1) Regression analysis

a) Regression analysis between independent variable and Dividends payment decision

This table provides a model summary between the indicators of independent variable and dividends payment decision.

Table 12 indicates the value of adjusted R Square was 0.897 and demonstration that there is modification of 0.902 on dividends payment decision owing to the modification in independent variable (ratio analysis, common size analysis Vertical analysis, horizontal analysis).

Calculated value of level of significance was 70.324. While a mean square at regression level was 17.578. The above consideration shows that the general approach was significant and that the indicators of independents variable and all 
have a positive impact on the dividends payment decision as shown in Table 13.

The finding revealed that holding independent variables constant (ratio, common size, vertical, and horizontal analysis) to a constant zero, ratio analysis would be at 0.454 , and, common size analysis at 539 can improve horizontal analysis limited by a factor of 0.068 as shown in Table 14 .

b) Regression analysis between independent variable and Short term investment decision

This table provides a model summary between the indicators of independent variable and short term investment decision.

From Table 15, the role of the adjustment made $\mathrm{R}$ is 0.901 evidences the change of 0.905 of $\mathrm{R}$ Square short term investment decision due to changes in the independent variable.

The calculated sum of Square 24.598 and the total mean Square was 10.346 at the regression level. The significance was 0.000 . This indicates the general approach was significant and independent variables, all affect positively short term investment decision.

The finding revealed that holding independent variables constant affect the short term investment decision to a constant zero, short term investment decision would be at 0.309 for common size analysis while the most significant $p$

Table 12. Model Summary.

\begin{tabular}{ccccc}
\hline \multicolumn{4}{c}{ Model Summary } \\
\hline Model & $\mathbf{R}$ & R Square & Adjusted R Square & Std. Error of the Estimate \\
\hline 1 & $0.950^{\mathrm{a}}$ & 0.902 & 0.897 & 0.29024 \\
\hline
\end{tabular}

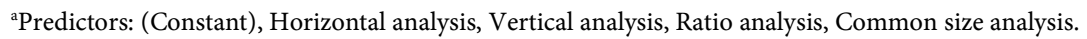

Table 13. Analysis of Variance (ANOVA).

\begin{tabular}{|c|c|c|c|c|c|c|}
\hline & Model & Sum of Squares & Df & Mean Square & $\mathbf{F}$ & Sig. \\
\hline \multirow{3}{*}{1} & Regression & 70.324 & 4 & 17.581 & 208.708 & $0.000^{\mathrm{a}}$ \\
\hline & Residual & 7.666 & 91 & 0.084 & & \\
\hline & Total & 77.990 & 95 & & & \\
\hline
\end{tabular}

${ }^{\text {a} P r e d i c t o r s: ~(C o n s t a n t), ~ H o r i z o n t a l ~ a n a l y s i s, ~ V e r t i c a l ~ a n a l y s i s, ~ R a t i o ~ a n a l y s i s, ~ C o m m o n ~ s i z e ~ a n a l y s i s . ~}$

Table 14. Dividends payment decision

\begin{tabular}{cccccc}
\hline \multirow{2}{*}{ Model } & \multicolumn{2}{c}{ Unstandardized Coefficients } & Standardized Coefficients & t & Sig. \\
\cline { 2 - 4 } & $\mathbf{B}$ & Std. Error & Beta & & \\
\hline (Constant) & 0.266 & 0.165 & & 1.616 & 0.110 \\
Ratio analysis & -0.039 & 0.101 & -0.029 & -0.388 & 0.699 \\
1 Common size analysis & 0.068 & 0.091 & 0.074 & 0.747 & 0.457 \\
Vertical analysis & 0.454 & 0.106 & 0.299 & 4.284 & 0.000 \\
Horizontal analysis & 0.539 & 0.081 & 0.668 & 6.680 & 0.000 \\
\hline
\end{tabular}


value was 0.004 . Therefore, an increase in Vertical analysis, horizontal analysis stimulate adequate ratio by a factor of 0.36 standardized significance at short term investment decision level. As shown in Table 17.

c) Regression analysis and long term investment decision

This table provides a model summary between the indicators of independent variable and long term investment decision.

Table 18 indicates the value of Adjusted R Square was 0.893 and demonstration that there is a change of $\mathrm{R}$ Square 0.898 enhanced the long term investment decision owing to adjustment in the independent variable in table above 18.

The calculated value was $0.16,0.460$ significance level at regression level while at the same level the sum of square was 7.493 and the total mean square was 0.119 , 0.904 . The aforementioned evidenced the general approach to be significantly and that independent variable and all have a positive effect the long term investment decision. As shown in Table 16.

The finding revealed that holding independent variables constant to a constant zero, Vertical analysis would be 0.421 and 0.330 for horizontal analysis and element enhanced ratio analysis in the term investment decision limited by a factor of 0.001 significantly correlated with the long term investment decision. As shown in Table 19.

Table 15. Model summary.

\begin{tabular}{ccccc}
\hline Model & R & R Square & Adjusted R Square & Std. Error of the Estimate \\
\hline 1 & $0.951^{\mathrm{a}}$ & 0.905 & 0.901 & 0.33718 \\
\hline
\end{tabular}

aPredictors: (Constant), Horizontal analysis, Vertical analysis, Ratio analysis, Common size analysis.

Table 16. ANOVA.

\begin{tabular}{cccccc}
\hline \multicolumn{1}{c}{ Model } & Sum of Squares & Df & Mean Square & F & Sig. \\
\hline \multirow{2}{*}{$\begin{array}{c}\text { Regression } \\
\text { Residual }\end{array}$} & 98.393 & 4 & 24.598 & 216.357 & $0.000^{\mathrm{a}}$ \\
& Total & 10.346 & 91 & 0.114 & \\
\end{tabular}

apredictors: (Constant), Horizontal analysis, Vertical analysis, Ratio analysis, Common size analysis.

Table 17. Regression coefficient.

\begin{tabular}{|c|c|c|c|c|c|c|}
\hline & \multirow[t]{2}{*}{ Model } & \multicolumn{2}{|c|}{$\begin{array}{l}\text { Unstandardized } \\
\text { Coefficients }\end{array}$} & \multirow{2}{*}{$\begin{array}{c}\begin{array}{c}\text { Standardized } \\
\text { Coefficients }\end{array} \\
\text { Beta }\end{array}$} & \multirow[t]{2}{*}{$\mathbf{t}$} & \multirow[t]{2}{*}{ Sig. } \\
\hline & & B & Std. Error & & & \\
\hline & (Constant) & -0.036 & 0.191 & & -0.188 & 0.851 \\
\hline & Ratio analysis & 0.076 & 0.117 & 0.048 & 0.651 & 0.516 \\
\hline \multirow[t]{3}{*}{1} & Common size analysis & 0.309 & 0.106 & 0.286 & 2.923 & 0.004 \\
\hline & Vertical analysis & 0.085 & 0.123 & 0.048 & 0.692 & 0.490 \\
\hline & Horizontal analysis & 0.575 & 0.094 & 0.604 & 6.135 & 0.000 \\
\hline
\end{tabular}


Table 18. Model summary.

\begin{tabular}{ccccc}
\hline Model & R & R Square & Adjusted R Square & Std. Error of the Estimate \\
\hline 1 & $0.948^{\mathrm{a}}$ & 0.898 & 0.893 & 0.28695 \\
\hline
\end{tabular}

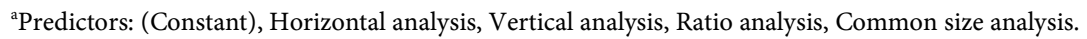

Table 19. ANOVA.

\begin{tabular}{ccccccc}
\hline & Model & Sum of Squares & Df & Mean Square & F & Sig. \\
\hline & Regression & 65.840 & 4 & 16.460 & 199.904 & $0.000^{\mathrm{a}}$ \\
1 & Residual & 7.493 & 91 & 0.082 & & \\
& Total & 73.333 & 95 & & & \\
\hline
\end{tabular}

apredictors: (Constant), Horizontal analysis, Vertical analysis, Ratio analysis, Common size analysis.

Table 20. Regression analysis.

\begin{tabular}{|c|c|c|c|c|c|c|}
\hline & \multirow[t]{2}{*}{ Model } & \multicolumn{2}{|c|}{$\begin{array}{l}\text { Unstandardized } \\
\text { Coefficients }\end{array}$} & \multirow{2}{*}{$\begin{array}{l}\text { Standardized } \\
\text { Coefficients } \\
\text { Beta }\end{array}$} & \multirow[t]{2}{*}{$\mathbf{t}$} & \multirow[t]{2}{*}{ Sig. } \\
\hline & & B & Std. Error & & & \\
\hline \multirow{5}{*}{1} & (Constant) & 0.174 & 0.163 & & 1.069 & 0.288 \\
\hline & Ratio analysis & 0.330 & 0.100 & 0.254 & 3.310 & 0.001 \\
\hline & Common size analysis & 0.188 & 0.090 & 0.212 & 2.092 & 0.039 \\
\hline & Vertical analysis & 0.421 & 0.105 & 0.286 & 4.015 & 0.000 \\
\hline & Horizontal analysis & 0.221 & 0.080 & 0.282 & 2.768 & 0.007 \\
\hline
\end{tabular}

\section{Summary, Conclusion and Recommendations}

\subsection{Analysis of Financial Statements Strategies in the Bank of KIGALI}

Results indicate that $60 \%$ show a great extent to which ratio analysis is used in Bank of Kigali. Findings, indicate that most of respondents 55\% show a great extent to which common size analysis is used in Bank of Kigali. As reflected, it was indicated $70 \%$ show a great extent to which vertical analysis is used in Bank of Kigali. Results show that $2.5 \%$ demonstrated a moderate extent horizontal analysis is adopted in Bank of Kigali.

\subsection{Identification of the Investment Decision Making Made by the Bank of Kigali-Rwanda}

The second objective identified the investment decision making made by the Bank of Kigali-Rwanda. These include the following but not exhaustive: dividends payment decision, short and long term investment decision.

Results show a great extent to which dividends payment decision is used in the Bank of Kigali, 30.0\% demonstrated a moderate extent dividends payment decision is adopted in the Bank of Kigali. Findings indicate that $60.0 \%$ show a 
great extent to which short term investment decision in the Bank of Kigali, and $12.5 \%$ demonstrated a moderate extent short term investment decision is adopted in the Bank of Kigali. Finally only $12.5 \%$ of respondents evidenced a little extent to which the short term investment decision is applied in the bank of Kigali. Results indicated 50.0\%. As showed in Table 20.

\subsection{Relationship between Financial Statement Analysis and Investment Decision Making in the Bank of Kigali}

Results illustrates correlation between financial statements analysis expressed in its mains components, investment decision making indicators as well as intervening variable as expressed in concept framework of this study.

Correlation between financial statements analysis and investment decision making

Findings showed that for the majority of variables they are not correlated. However some of them were found to be correlated where for example a weak and positive relationship is discovered between vertical analysis and short term investment $0.790, \mathrm{p}$ value $=0.000$. Also a weak and negative correlation was found between vertical analysis and dividend payment decisions 756 with a $\mathrm{P}$ value of 0.000 . However, the aforementioned come from the weakness found for financial statement analysis within the Bank of Kigali and researcher call for BK management to address the main causes of financial statements analysis showed in previous section for improved investment decision making.

Regression analysis between control system and financial performance

The finding revealed that holding independent variables constant to a constant zero, short term investment decision would be at 0.266 for common size analysis while the most significant $\mathrm{p}$ value was 0.008 . The finding revealed that holding independent variables constant to a constant zero, Vertical analysis would be at 0.215 for horizontal analysis and element enhanced ratio analysis in the term investment decision limited by a factor of 0.001 correlated with the long term investment decision.

\subsection{Conclusion}

It is concluded that understanding financial statement analysis provides that is very important to those who have the businesses as tools for reducing the considerable risks involved in starting and growing the business. This was envisaged in analysis financial statements for the Bank of Kigali from 2014 to 2018 by utilized horizontal analysis as one of the best used of financial statement analysis that allowed Bank of Kigali to compare the performance of its business in that period. In conclusion the researcher found out that bank of Kigali ratio analysis is used in Bank of Kigali at the significant level. It was indicated that most of respondents show $55 \%$ show a great extent to which common size analysis is used in Bank of Kigali.

Therefore, financial statements analysis done for Bank of Kigali was vital for 
the enhancement of its performance in making decision related to investment.

The second objectives identified the investment decision making made by the Bank of Kigali-Rwanda. These include the following but not exhaustive: dividends payment decision, short, and long term investment decision making. It was indicated that dividends payment decision is used in the Bank of Kigali, Findings indicates that $60.0 \%$ show a great extent to which short term investment decision in the Bank of Kigali. Results presented in Table 9 indicated $50.0 \%$ show a great level long term investment decision is used in the Bank of Kigali, $20.0 \%$ for a very extent and $22.5 \%$ demonstrated a moderate extent long term investment decision is adopted in Bank of Kigali.

As regards to financial statement analysis as a pillar to draw conclusions and decisions pertaining the company's performance the findings showed that earnings for BK resulted from the board decisions that turned around the loan portfolio which had deteriorated following the global financial crisis thereby enhancing loan provisioning for the accounts that failed to honor their instalments.

In respect to staff and shareholder perception the results are concluded that with the challenges the bank faced in different years. This resulted from the Bank's decisions to enhance loss provisioning for the accounts that failed to honor their instalments while upgrading its core banking system to match with expanding operations.

In respect to the extent to which financial statement analysis led to desired decisions, BK decisions enhanced performance in information technology and communications infrastructures, improving customer services as well as enhancing the bank's funding and capital management. The decisions enabled the bank to raise its interest income while reducing interest expenses that produced a net interest income. Therefore, the bank implemented its decision to review a treasury management system that improved the management of risk in the bank by changing risk management practices. The ratio indicates that the firm is performing well since for a healthier firm to have productivity, the net profit margin should neither be high nor low. Calculated value of level of significance was 0.036 . While a mean square at regression level was 1.828 . The finding revealed that holding independent variables constant to a constant zero, short term investment decision would be at 0.266 for common size analysis while the most significant $p$ value was 0.008 . The finding revealed that holding independent variables constant to a constant zero, Vertical analysis would be at 0.215 for horizontal analysis and element enhanced ratio analysis in the term investment decision limited by a factor of 0.001 significantly correlated with the long term investment decision.

\subsection{Recommendation for Policy}

In light of the above findings, the following are the recommendations:

The financial status of BK needs to be maintained while enhancing quality de- 
cisions for better service provision.

The stakeholders were interested on the adequacy of funds in order to have confidence on savings and service provision. It is recommended to always mitigate risks while enhancing innovations and development.

There is a need to invest in business, technology, product development, training and effective risk management systems that may be facilitated by bold decisions for the life of the company.

\subsection{Suggestion for Further Studies}

Further research is recommended to the role of common size analysis to the investment decision making in the Bank of Kigali in Rwanda. The research proposed that future researches would involve qualitative discussion of the benefits of financial statements analysis on financial performance of banks.

There is a need to conduct more documentary review on BK financial statement analysis and its implications in other financial institutions in Rwanda.

\section{Conflicts of Interest}

The authors declare no conflicts of interest regarding the publication of this paper.

\section{References}

Afolabi, M. O. (2013). Effect of Financial Statements on Investment Decision Making of Manufacturing Firms in Nigeria. European Journal of Humanities and Social Sciences, 22, 1127-1142.

Alfred, N. (2013). Equity Market Performance and Its Effect on Economic Growth of a Country-Rwanda Stock Exchange. International Journal of Economics, Finance and Management, 2, 261-265.

Ali, I. M. (2011). Commercial Banks \& Historical Development. Journal of Applied Sciences Research, 7, 1024-1029.

American Institute of Certified Public Accountants [AICPA] (2013). Financial Statements Framework for Small and Medium Sized Entities. New York: CICA.

Barry, E., \& Jamie, E. (2011). Financial Accounting and Reporting. Harlow: Financial Times Prentice Hall.

Capital Market Authority [CMA] (2013). Capital Market Authority Annual Report 2013. Kigali: Capital Market Authority.

David, S. K. (2006). Financial Institutions, Markets and Money. Hoboken, NJ: John Wiley \& Sons.

Deming, S. H. (2005). International Financial Statements Standard: Their Importance to US Business and Legal Practice. New York: Michigan Bar Journal.

Donald, K. K., \& Delno, L. A. T. (2006). Proposal and Thesis Writing: An Introduction. Nairobi: Paulines Publications Africa, Dauggters of St. Paul.

Ebimobowei, G. O. (2012). Effect of Ethical Accounting Standards on the Quality of Financial Reports of Banks in Nigeria. Current Research Journal of Social Sciences, 4, 69-78.

Fisseha, F. L. (2015). Meta Analysis on the Determinants of Commercial Bank's Profita- 
bility: (A Conceptual Frame Work and Modelling). European Scientific Journal, ESJ, 11. http://eujournal.org/index.php/esj/article/view/5947

Hassan, S. U. (2013). Financial Statements Quality, Does Monitoring Characteristics Matter? An Empirical Analysis of Nigeria Manufacturing Firms. Journalof Business \& Management Review, 3, 147-161.

Hawariah, \& Dalnial, A. K. (2014). Detecting Fraudulent Financial Statements through Financial Statement Analysis. Journal of Advanced Management Science, 2, 17-22. https://doi.org/10.12720/joams.2.1.17-22

Higgins, R. C. (2012). International Financial Statements and Analysis. New York: McGraw-Hill.

Ingram (1994). Financial Accounting Information for Decision. London: Ingram.

International Monetary Fund [IMF] (2011). Financial System Stability Assessment. Washington DC: International Monetary Fund. https://doi.org/10.5089/9781455213764.002

Kamardin, A. E. (2014). Adoption of International Financial Statements Standards in Nigeria. Journal of Advanced Management Science, 2, 72-75. https://doi.org/10.12720/joams.2.1.72-75

Kariuki, G., \& Jagongo, A. (2013). Institutional Investors' Perceptions on Quality of Financial Statements in Kenya. International Journal of Humanities and Social Science, 3, 144-156.

Kothari, C. (2004). Research Methodology Methods \& Techniques. New Delhi: New Age International Publisher.

Kusa, V. O. (2013). Determinants of Financial Performance of Commercial Banks in Kenya. International Journal of Economics and Financial Issues, 3, 237-252.

Mckeith, B. C. (2010). Financial Accounting and Reporting. London: McGraw-Hill Education.

Ojo, J. O. (2012). Compliance with Regulatory Financial Statements and Corporate Governance. International Journal of Business and Social Science, 3, 246-254.

Penman, S. (2007). Financial Statement Analysis and Security Valuation. New York: McGraw-Hill.

Rwemalika, E. (2013). Financial Statements Analysis and the Performance of Commercial Banks in Rwanda: A Case Study of Bank of Kigali.

Solberg, C. A., \& Durrieu, F. (2006). Access to Networks and Commitment to Internationalisation as Precursors to Marketing Strategies in International Markets. Management International Review, 46, 57-83. https://doi.org/10.1007/s11575-007-0049-6

Vincent \& Schipper (2003). Financial Statements Issues. Valuation Implications of Reliability Differences. Journal of Accounting, 72, 351-383.

Westfall, L. (2009). Sampling Methods. London: The Westfall Team. 